Bài báo khoa học

\title{
Thiết lập mô hình cân bằng nước phục vụ lập quy hoạch tổng hợp lưu vực sông Cửu Long
}

\section{Nguyễn Ngọc Hà ${ }^{1 *}$, Hoàng Thị Nguyệt Minh², Đinh Tiến Dũng ${ }^{1}$}

${ }^{1}$ Trung tâm Quy hoạch và Điều tra Tài nguyên Nước Quốc gia, Bộ Tài Nguyên và Môi trường, 93/95 Vũ Xuân Thiều, Sài Đồng, Long Biên, Hà Nội; ha_tnn@yahoo.com; dungdt812@gmail.com

${ }^{2}$ Khoa Tài nguyên nước, Trường Đại học Tài nguyên và Môi trường Hà Nội; htnminh.tnn@hunre.edu.vn

*Tác giả liên hệ: ha_tnn@yahoo.com; Tel.: +84-989668363

Ban Biên tập nhận bài: 8/7/2021; Ngày phản biện xong: 27/8/2021; Ngày đăng bài: $25 / 11 / 2021$

Tóm tắt: Bài báo này nghiên cứu áp dụng mô hình cân bằng nước MIKE HYDRO BASIN (MHB) để đánh giá khả năng đáp ứng của nguồn nước cho các nhu cầu sử dụng nước khác nhau trên lưu vực sông (LVS) Cửu Long. Toàn bộ LVS được phân thành 120 vùng quản lý tổng hợp nguồn nước. Nhu cầu sử dụng nước được tính toán cho 6 mục đích sử dụng gồm sinh hoạt, công nghiệp, trồng trọt, chăn nuôi, nuôi trồng thủy sản, các nhu cầu khác và được giới hạn ở nước ngọt. Mô hình MHB tính toán cân bằng nước theo thời đoạn ngày cho năm hiện trạng 2020, nhằm xác định chi tiết tổng lượng nước thiếu cả năm, thời gian thiếu nước trong năm, các tháng thiếu nước trên toàn LVS và trên 120 vùng quản lý tổng hợp nguồn nước. Kết quả tính toán cho thấy, tổng lượng nước thiếu cả năm trên toàn LVS chiếm khoảng $11,4 \%$ tổng nhu cầu sử dụng nước, thời gian thiếu nhiều nhất vào tháng 2-4 (19,1-19,6\%), khu vực thiếu nhiều nhất là vùng bán đảo Cà Mau. Mô hình MHB áp dụng với LVSCL có thể được sử dụng như một công cụ đánh giá nhanh và thuận tiện để đánh giá khả năng đáp ứng của nguồn nước ứng với các kịch bản quy hoạch khác nhau, từ đó làm cơ sở cho việc lựa chọn các phương án phân bổ nguồn nước phù hợp.

Từ khóa: Cân bằng nước; Cửu Long; Mê Kông; Mike Hydro Basin; Tài nguyên nước.

\section{Mở đầu}

LVSCL có vị trí rất quan trọng trong phát triển kinh tế-xã hội của cả nước. Với tiềm năng nông nghiệp lớn, trong nhiều năm qua, LVSCL luôn đóng góp khoảng $50 \%$ tổng sản lượng lương thực cả nước, bên cạnh vai trò chủ đạo trong xuất khẩu gạo, LVSCL cung cấp $70 \%$ lượng trái cây, $65 \%$ sản lượng thuỷ sản của cả nước [1]. Nguồn nước LVSCL được đánh giá là dồi dào, tuy nhiên trong những năm trở lại đây tài nguyên nước trên LVS đã và đang đối mặt với nhiều thách thức nghiêm trọng như nước biển dâng, hạn hán, thiếu nước, gia tăng xâm nhập mặn, xói lở bờ sông, bờ biển, sụt lún đất... Nguyên nhân thực trạng trên là do khai thác và sử dụng tài nguyên nước quá mức, không hợp lý và hiệu quả LVS, đặc biệt là ở thượng lưu Mê Công. Đồng thời ảnh hưởng của biến đổi khí hậu cũng như cách phối hợp trong quản lý tài nguyên nước góp phần quan trợng dẫn đến các vấn đề trên. Như vậy, quy hoạch tổng hợp LVSCL sẽ là công cụ hiệu quả hỗ trợ quản lý tổng hợp tài nguyên nước, đồng thời làm cơ sở cho việc điều chỉnh và định hướng khai thác, sử dụng nước, bảo vệ tài nguyên nước của các ngành cũng như định hướng về hợp tác với các quốc gia thượng lưu. Để hô̂ trợ 
xây dựng quy hoạch, việc đánh giá mức độ đáp ứng của nguồn nước đối với các nhu cầu sử dụng nước khác nhau cho dân sinh, kinh tế, xã hội, môi trường thông quan tính toán cân bằng nước là vô cùng quan trọng.

Do đặc điểm dòng chảy LVSCL ảnh hưởng sâu sắc bởi thủy triều biển Đông và biển Tây, với hệ thống kênh rạch phức tạp, không có lưu vực rõ ràng. Vì vậy, từ trước tới nay, việc tính toán cân bằng nước trên LVSCL thường được thực hiện đơn giản qua so sánh lượng nước đến và nhu cầu trên phạm vi toàn vùng, tiểu vùng lớn (vùng tả sông Tiền, giữa 2 sông Tiền-sông Hậu, Tứ giác Long Xuyên, bán đảo Cà Mau), hoặc đánh giá chi tiết thông qua mô hình thủy lực, tuy nhiên do tính phức tạp của mạng lưới sông và chế độ dòng chảy, kết quả tính toán chưa đủ linh hoạt để áp dụng đánh giá các phương án khai thác-sử dụng nước và đưa ra các định hướng phân bổ tài nguyên nước trên lưu vực. Các mô hình cân bằng nước thông thường như WEAP, MIKE HYDRO BASIN (MHB) mặc dù không thực sự phù hợp với dòng chảy 2 chiều nhưng có thế mạnh trong việc tính toán cân bằng nước với nhiều kịch bản linh hoạt của nước đến, nhu cầu sử dụng nước, có xét đến các công trình khai thác trên lưu vực [2-3].

Bài báo nghiên cứu thiết lập mô hình $\mathrm{MHB}$ để đánh giá mức độ đáp ứng của nguồn nước đối với các nhu cầu sử dụng nước khác nhau ứng với các kịch bản khác nhau. Các kết quả tính toán sẽ làm cơ sở cho việc lựa chọn các phương án phân bổ nguồn nước phù hợp phục vụ lập quy hoạch tổng hợp LVSCL.

\section{Phương pháp nghiên cứu}

\subsection{Khu vưc nghiên cúu}

LVS Cửu Long (LVSCL) thuộc châu thổ sông Mê Công, nằm ở Tây Nam bộ, có vị trí liền kề với LVS Đồng Nai, phía Bắc giáp Campuchia, phía Tây-Nam là vịnh Thái Lan và phía Đông-Nam là biển Đông. LVS bao gồm 13 tỉnh với tổng diện tích là $39.945 \mathrm{~km}^{2}$, và dân số là 17,738 triệu người (2017), chiếm 20,53\% dân số cả nước [4].

Hệ thống sông, kênh ở LVSCL được phát triển chủ yếu trong vòng hơn thế kỷ nay, với mục đích chính là phát triển nông nghiệp và giao thông thủy. Đến nay, hệ thống kênh đào đã được đan dày ở cả 3 cấp là kênh trục/ kênh cấp 1 , kênh cấp 2 và kênh cấp 3 nội đồng, hợp thành một hệ thống kênh mương khá dày, với mật độ 8-10 $\mathrm{m} / \mathrm{ha}$. Điểm đặc biệt đây là hệ thống kênh mở và bán mở nên mọi tác động vào bất kỳ vị trí nào trong hệ thống kênh này đều có thể lan truyền ảnh hưởng đến các vùng lân cận. Bên cạnh mặt lợi, hệ thống kênh đào làm dòng chảy của các sông tự nhiên mất tính độc lập ảnh hưởng đến dòng chảy sông Mê Công, đồng thời tác động gián tiếp làm thủy triều và mặn xâm nhập sâu hơn vào đồng, dẫn đến chế độ dòng chảy nội đồng trở nên hết sức phức tạp [5-6].

Tổng lượng dòng chảy sông Mê Công hàng năm ra biển khoảng 500 tỷ $\mathrm{m}^{3}$, trong đó chảy vào LVSCL trên 475 tỷ $\mathrm{m}^{3}$ [5]. Với lượng mưa trung bình vào khoảng $1.600-1.800 \mathrm{~mm}$, lượng nước nội tại sinh ra trên lưu vực khoảng 25 tỷ $\mathrm{m}^{3}$ (chiếm $5 \%$ tổng lượng dòng chảy). Lưu lượng trung bình năm trên lưu vực giai đoạn 2000-2020 theo số liệu thực đo tại Tân Châu và Châu Đốc là $12.572 \mathrm{~m}^{3} / \mathrm{s}$ (Tân Châu là $10.142 \mathrm{~m}^{3} / \mathrm{s}$, Châu Đốc là $2.430 \mathrm{~m}^{3} / \mathrm{s}$ ). Tỷ lệ phân phối lưu lượng trung bình cả năm từ Phnômpênh vào sông Tiền và sông Hậu qua Tân Châu và Châu Đốc là $83 \% / 17 \%$ khá ổn định, có xu thế thấp hơn trong mùa lũ $(80 \% / 20 \%)$ và cao hơn trong mùa kiệt (84-86\%/14-16\%). Tuy nhiên, khi vào sâu hơn trong đồng bằng, với sự điều tiết của Vàm Nao, dòng chảy 2 sông đã lập lại thế cân bằng với $51 \%$ cho sông Tiền và $49 \%$ cho sông Hậu [7].

Chế độ nước trên LVSCL chia làm 2 mùa rõ rệt: mùa lũ và mùa kiệt. Mùa lũ từ tháng 7 đến tháng 11 (90\% tổng lượng nước hàng năm) và mùa kiệt từ tháng 12 năm trước đến tháng 5 năm sau (chiếm 10\% tổng lượng nước), dòng chảy kiệt nhất xuất hiện vào tháng 3,4 .

Dòng chảy trong mùa kiệt chịu ảnh hưởng lớn của thủy triều, tuy thuận lợi trong tiêu và cấp nước, nhưng việc hình thành các giáp nước và sự cạn kiệt dòng chảy khi triều rút, kỳ 
triều kém cũng gây trở ngại cho phát triển. Trong chu kỳ 15 ngày, những ngày triều cường là thời kỳ tích nước tạm thời trong kênh rạch nội đồng và làm tăng mực nước trung bình và ngược lại. Vào cuối mùa lũ, khi nguồn nước từ thượng lưu về trong sông giảm dần, mặn từ biển bắt đầu lấn dần vào vùng cửa sông và theo triều xâm nhập sâu hơn trong nội đồng [6].

Đối với tài nguyên nước dưới đất (NDĐ), ở LVSCL có 6 tầng chứa nước chính có khả năng khai thác với quy mô lớn với trữ lượng khai thác NDĐ nhạt $(\mathrm{M}<1,0 \mathrm{~g} / \mathrm{l})$ là 22.513 .000 $\mathrm{m}^{3} /$ ngày và trữ lượng khai thác $\mathrm{NDĐ}$ mặn $(\mathrm{M}>1,0 \mathrm{~g} / \mathrm{l})$ là $39.124 .000 \mathrm{~m}^{3} /$ ngày $[5,8]$.

Tình hình cấp nước tại các đô thị LVSCL được cải thiện đáng kể trong 10 năm trở lại đây. Tỷ lệ người dân dùng nước sạch đạt $70 \%$, xấp xỉ mức bình quân cả nước. Định mức tiêu thụ nước sạch/đầu người nâng lên 80-100 1/người/ngày. Tổng công suất cấp nước sạch của vùng khoảng $700.000 \mathrm{~m}^{3} /$ ngày, trong đó có $50 \%$ nguồn nước ngầm. Các hình thức cấp nước ở nông thôn gồm cấp nước tập trung ( $19 \%$ dân số), từ các giếng khoan $(26,4 \%$ dân số), giếng đào $(22 \%$ dân số) và nước mưa $(32,6 \%$ dân số) [5].

\subsection{Số liệu và phwơng pháp}

\subsubsection{Số liệu đầu vào}

Hệ thống sông gồm: sông Mê Công với 2 dòng chính là sông Tiền, sông Hậu, các phân lưu ra biển và sông nối Vàm Nao, 2 sông quốc tế là sông Vàm Cỏ Tây-Vàm Cỏ Đông và sông Giang Thành, ngoài ra còn có các sông nội địa như Cái Lớn, Cái Bé, Mỹ Thanh, Gành Hào, Ông Đốc, Bảy Háp và một số rạch nhỏ tự nhiên khác [9].

Số liệu khí tượng, thủy văn giai đoạn 1980-2019 được thu thập, tổng hợp, phân tích từ nhiều nguồn [10-11] làm đầu vào cho các mô hình mưa-dòng chảy MIKE NAM và mô hình thủy lực MIKE 11 để tính toán dòng chảy nội sinh và ngoại sinh vào vùng nghiên cứu, bao gồm dòng chảy từ Campuchia qua sông Mê Kông và các nhánh sông dọc biên giới, thượng lưu sông Vàm Cỏ và LVS Đồng Nai. Mô hình MIKE NAM được sử dụng để tính dòng chảy sản sinh từ mưa trên lưu vực sông Mê Kông tính từ Kratie đến hết vùng LVSCL và LVS Đồng Nai, với phương pháp tương tự như [12-13].

Số liệu trữ lượng có thể khai thác nước dưới đất được kế thừa từ kết quả tính toán trong nhiệm vụ lập quy hoạch tổng hợp LVSCL $[5,8]$.

Nhu cầu sử dụng nước cho 6 loại mục đích (sinh hoạt, công nghiệp, trồng trọt, chăn nuôi, thủy sản, khác) được tính toán từ số liệu trong niên giám thống kê 13 tỉnh vùng LVSCL năm 2020, bản đồ sử dụng đất nông nghiệp của Đại học Cần Thơ năm 2017, và bản đồ sử dụng đất của Bộ Tài nguyên và Môi trường năm 2015. Việc tính toán nhu cầu nước cho trồng trọt và thủy sản có sử dụng lịch thời vụ các loại cây trồng và các mô hình thủy sản kết hợp từ các quy hoạch thủy lợi $[6,14]$. Nhu cầu cấp nước cho sinh hoạt, công nghiệp có tham khảo từ quy hoạch cấp nước vùng đồng bằng sông Cửu Long [15-16].

\subsubsection{Phân vùng tính toán}

Tương đồng với Quy hoạch vùng ĐBSCL [16], quy hoạch tổng hợp LVSCL phân chia toàn vùng thành 12 tiểu vùng quy hoạch ứng với 3 vùng sinh thái theo độ mặn: vùng ngọt, vùng lợ và vùng mặn. Để đảm bảo mức độ chi tiết khi đánh giá tài nguyên nước cho các tiểu vùng quy hoạch này, trong nghiên cứu phân chia LVSCL thành 120 vùng quản lý tổng hợp nguồn nước (Hình 1). Việc phân chia này tạo thuận lợi và đảm bảo sự linh hoạt cho công việc tổng hợp kết quả tính toán sau này. 

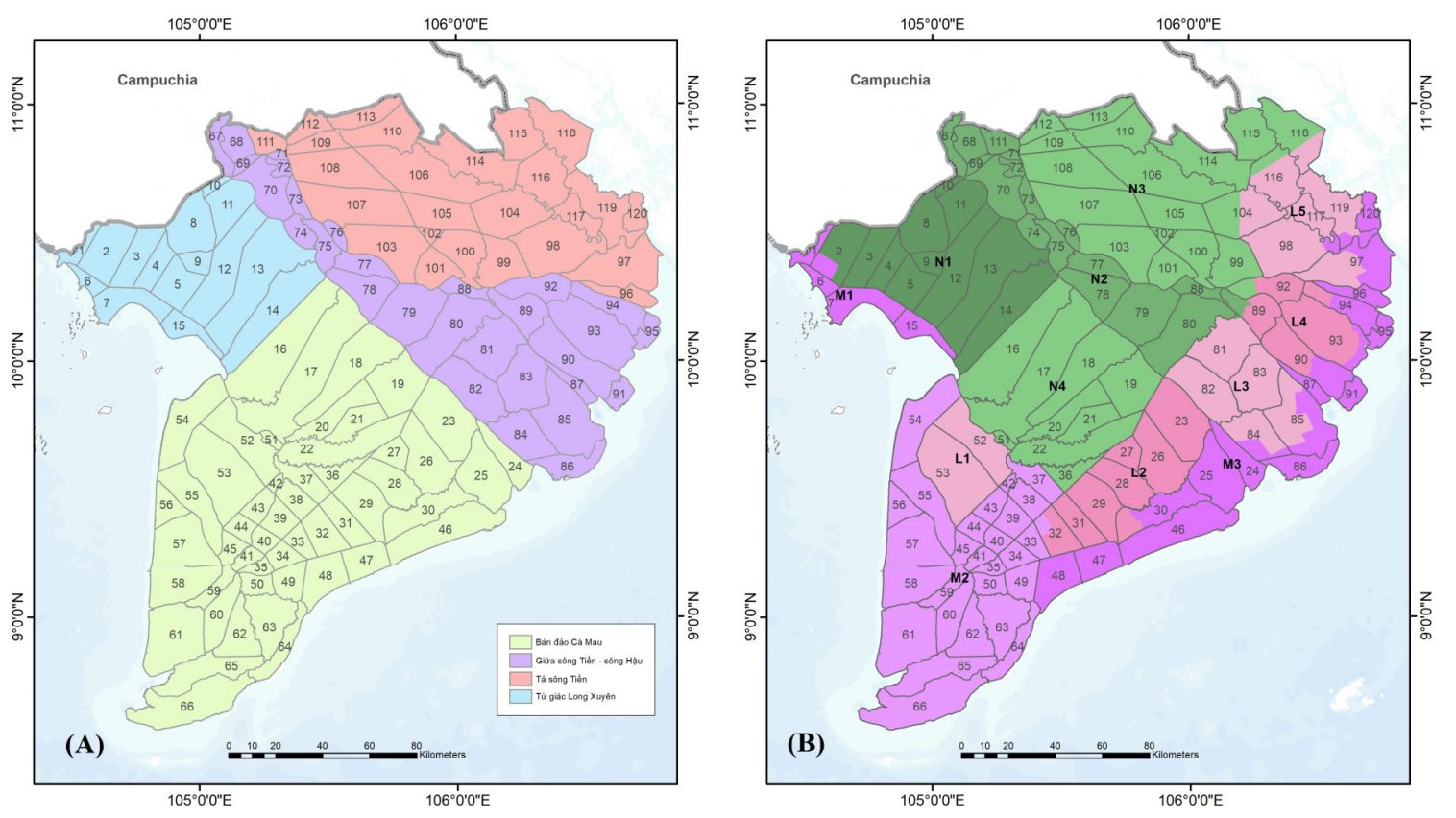

Hình 1. Phân vùng tính toán cân bằng nước theo $(\mathrm{A})$ quy hoạch thủy lợi và $(\mathrm{B})$ vùng sinh thái: vùng ngọt (N1-N4), vùng lợ (L1-L5), vùng mặn (M1-M3).

\subsubsection{Thiết lập sơ đồ tính toán}

Mạng sông thiết lập trong mô hình MHB gồm 130 sông, kênh, trong đó, 43 sông thuộc quy hoạch tổng hợp LVSCL là các sông liên tỉnh, nguồn nước liên tỉnh. Các sông, kênh được chọn đều là kênh trục lớn hoặc là biên của các khu sử dụng nước (Hình 2a).

Do đặc điểm chịu ảnh hưởng mạnh của thủy triều biển Đông và biển Tây, dòng chảy trong hệ thống sông, kênh vùng LVSCL, bao gồm cả dòng chảy tại Tân Châu và Châu Đốc, đều là 2 chiều (lưu lượng giờ âm hoặc dương) phụ thuộc vào lúc triều lên hay triều rút. Chế độ thủy triều là bán nhật triều hoặc bán nhật triều không đều nên trong ngày thường có 2 lần triều lên và 2 lần triều rút. Mô hình $\mathrm{MHB}$ chỉ cho phép thiết lập dòng chảy cố định 1 chiều, do đó chiều được lựa chọn trong mạng sông thiết lập là chiều của lưu lượng trung bình thời đoạn dài (tháng). Cách thiết lập này mặc dù không mô phỏng chính xác chế độ dòng chảy thực tế, nhưng phù hợp với xu hướng chung của dòng chảy và mục đích đánh giá khả năng đáp ứng nhu cầu nước ngọt trong thời đoạn dài, đồng thời đảm bảo sự đơn giản và linh hoạt cần thiết trong việc đánh giá các phương án, kịch bản phân bổ nguồn nước khác nhau. Mặt khác, từ trước tới nay, việc tính toán tài nguyên nước đến vùng LVSCL vẫn sử dụng cách tính lưu lượng trung bình tại 2 trạm Tân Châu và Châu Đốc (mặc dù lưu lượng theo giờ tại đây vẫn có giá trị âm và dương trong ngày). Việc sử dụng mô hình MIKE BASIN (phiên bản cũ hơn của MIKE HYDRO BASIN-MHB) trong tính toán cân bằng nước tại LVS Mê Kông cũng đã được thực hiện trong dự án Nghiên cứu đánh giá tác động của các công trình trên thủy điện dòng chính Mê Kông, sử dụng kết hợp các mô hình SWAT-MIKE 11-MIKE 21MIKE BASIN [17]. Mặc dù vậy, áp dụng các mô hình này tại vùng đồng bằng LVSCL ở chỉ dừng lại ở cân bằng nước trên vùng lớn. Việc ứng dụng mô hình MHB tại LVSCL để cân bằng nước chi tiết đến 120 vùng gặp nhiều thách thức do hạn chế của mô hình, tuy nhiên khả năng áp dụng là hoàn toàn có thể khi xem xét một số giả định và mục đích bài toán.

Chiều dòng chảy được lựa chọn trong mô hình phù hợp với chiều lấy nước quy ước trong thủy lợi (xem Hình 2b), cụ thể:

- Vùng tả sông Tiền: lấy nước từ sông Tiền qua 2 hướng chính là Tây-Đông và Tây BắcĐông Nam. biển.

- Vùng giữa 2 sông: lấy nước từ sông Tiền sang sông Hậu và Tây Bắc-Đông Nam về 
- Vùng tứ giác Long Xuyên: lấy nước từ sông Hậu và đổ ra biển Tây hoặc chuyển xống vùng bán đảo Cà Mau. xuống.

- Vùng bán đảo Cà Mau: lấy nước từ sông Hậu và từ vùng tứ giác Long Xuyên chảy

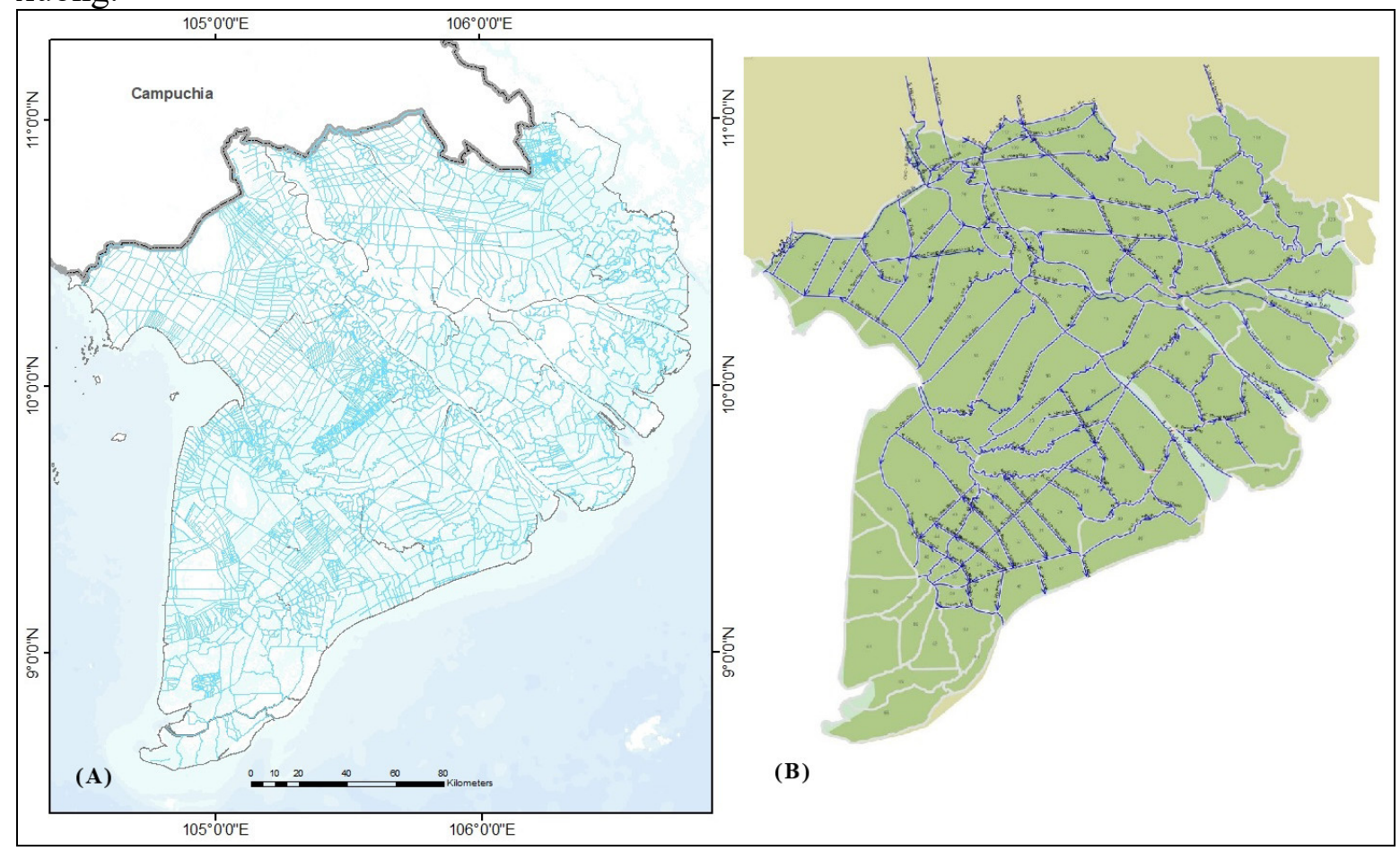

Hình 2. (A) hệ thống sông, kênh trục cấp 1, 2 trên LVSCL và (B) sơ đồ mạng sông thiết lập trong mô hình MHB.

\subsubsection{Thiết lập số liệu đầu vào}

Dòng chảy ngoại sinh về vùng LVSCL được đưa vào mô hình thông qua các nút lưu vực (catchment) tại sông Tiền, sông Hậu trên biên giới Việt Nam-Campuchia, tại một số nhánh chính chảy qua biên giới, và tại thượng lưu sông Vàm Cỏ Đông.

Dòng chảy nội sinh từ mưa được đưa vào mô hình thông qua 120 nút ứng với $120 \mathrm{khu}$ sử dụng nước. Các nút này phân bổ dòng chảy đến từng điểm lấy nước trên các sông, kênh biên của khu sử dụng nước với các hệ số phân bổ xác định. Đối với nguồn nước dưới đất, tương tự có 120 nút mô phỏng cho 120 khu sử dụng nước. Nhu cầu sử dụng nước ứng với 6 mục đích được mô phỏng bằng 6 đối tượng sử dụng nước (user) cho mỗi khu sử dụng nước. Tổng cộng có 720 user được thiết lập (Hình 3).

\subsubsection{Thiết lập các quy tắc}

Khác với bài toán cân bằng nước cho một lưu vực thông thường, đối với LVSCL hay vùng tương tự không có lưu vực rõ ràng, kết quả cân bằng nước phụ thuộc rất nhiều vào việc xác định các quy tắc phân bổ nhằm mô phỏng gần nhất với điều kiện sử dụng thực tế hoặc các kịch bản. Các quy tắc này được thể hiện trong các thông số dưới đây.

Tỉ lệ phân bổ lượng nước nội sinh vào các kênh: mỗi khu sử dụng nước đều được bao bởi các sông, kênh. Mỗi sông, kênh này được coi là một nguồn cấp nước mặt cho các đối tượng sử dụng nước của khu đó. Lượng nước mặt nội sinh từ mưa rơi trên khu sử dụng nước đang xét được phân bổ cho các sông, kênh này với tỉ lệ được xác định dựa trên mật độ sông, kênh kết nối với sông, kênh đang xét, với ý nghĩa mật độ càng dày thì càng nhận được nhiều nước. Để đơn giản hóa, có thể lấy tỉ lệ phân bổ đều:

$$
\mathrm{Q}_{\mathrm{i}}=\mathrm{Q}_{\mathrm{ns}} / \mathrm{n}_{\mathrm{k}}
$$


Trong đó $\mathrm{Q}_{i}$ là lưu lượng dòng chảy nội sinh trên khu đang xét phân bổ tới kênh biên i; $\mathrm{Q}_{\mathrm{ns}}$ là tổng dòng chảy nội sinh trên khu đang xét; $\mathrm{n}_{\mathrm{k}}$ là số kênh biên.

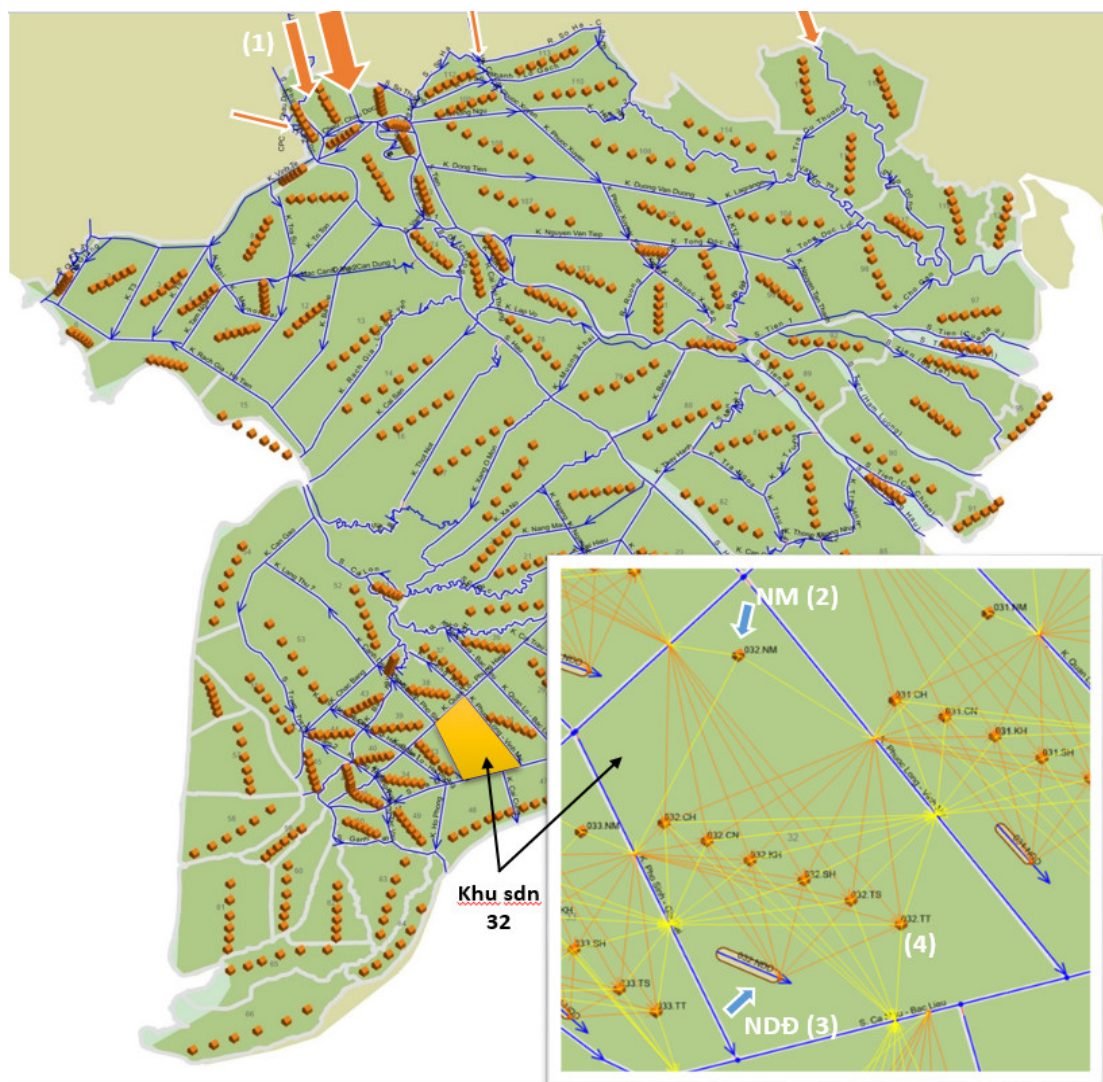

Hình 3. Mô hình hóa các đối tượng và thiết lập số liệu đầu vào: (1) Dòng chảy đến ngoại sinh, (2) Nước mặt nội sinh, (3) Nước dưới đất, (4) Đối tượng sử dụng nước.

Tỉ lệ phân luu (bifurcation): do đặc điểm hệ thống sông, kênh dày đặc, mạng sông tính toán bao gồm 92 nút phân lưu. Tỉ lệ phân lưu tại mỗi nút được xác định bằng tỉ lệ lưu lượng dòng chảy ra sông nhánh trên tổng lưu lượng dòng chảy đến nút. Sự phân chia dòng chảy trong mạng sông LVSCL là tương đối ổn định [18]. Trong nghiên cứu này, tỉ lệ phân chia được xác định từ kết quả tính toán của mô hình thủy lực và được nhập vào mô hình $\mathrm{MHB}$ dưới dạng đường quan hệ lưu lượng sông nhánh/sông chính (Hình 4-7).

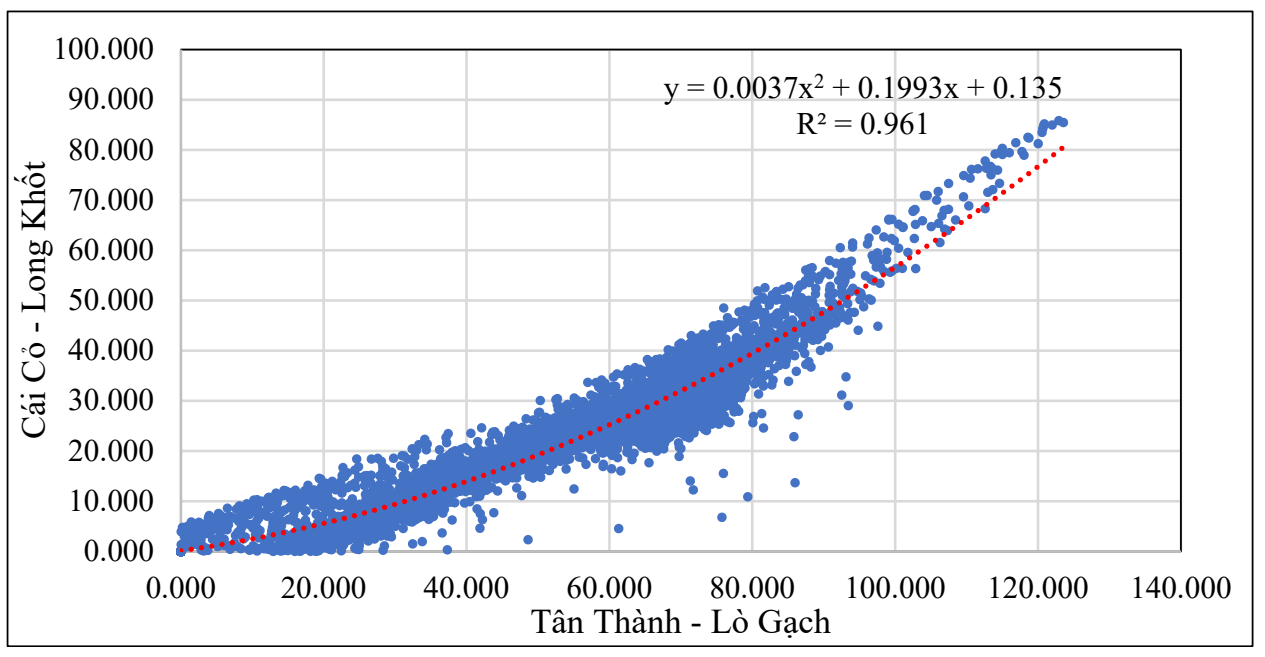

Hình 4. Đường quan hệ lưu lượng giờ tại nút phân lưu giữa kênh Tân Thành-Lò Gạch và kênh Cái Cỏ-Long Khốt. 


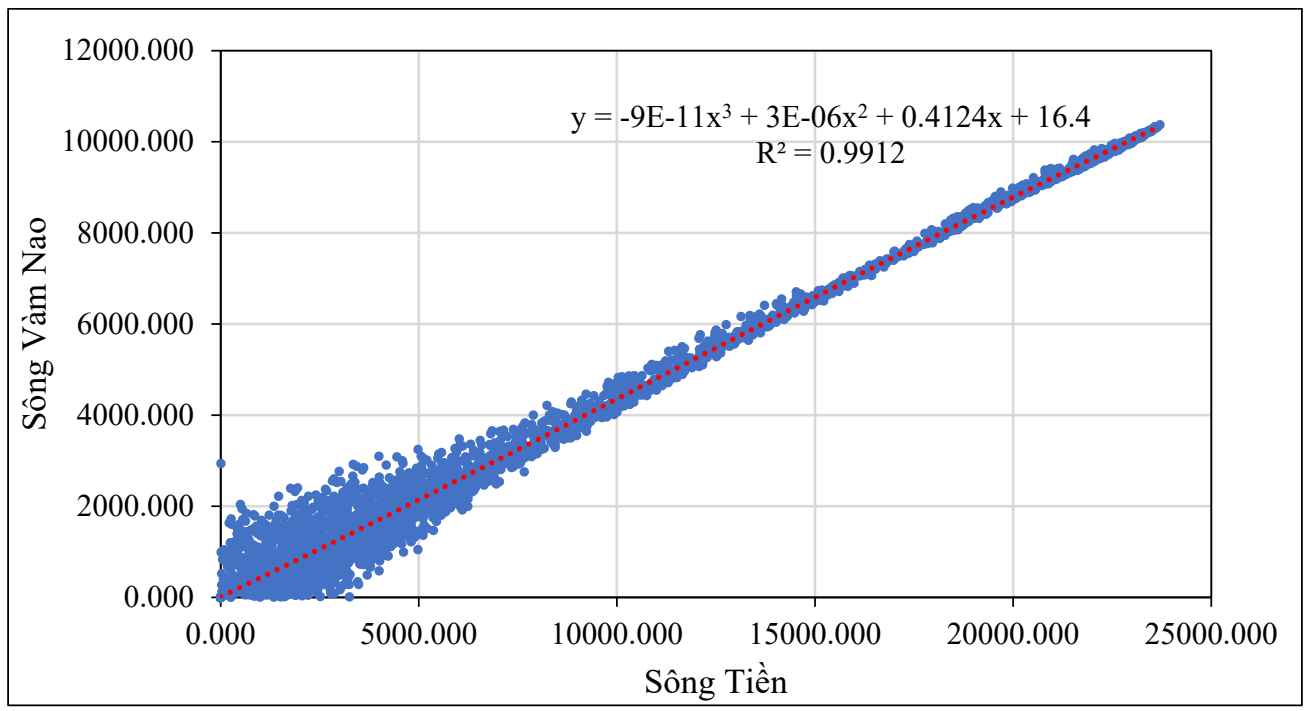

Hình 5. Đường quan hệ lưu lượng giờ tại nút phân lưu giữa sông Tiền và sông Vàm Nao.

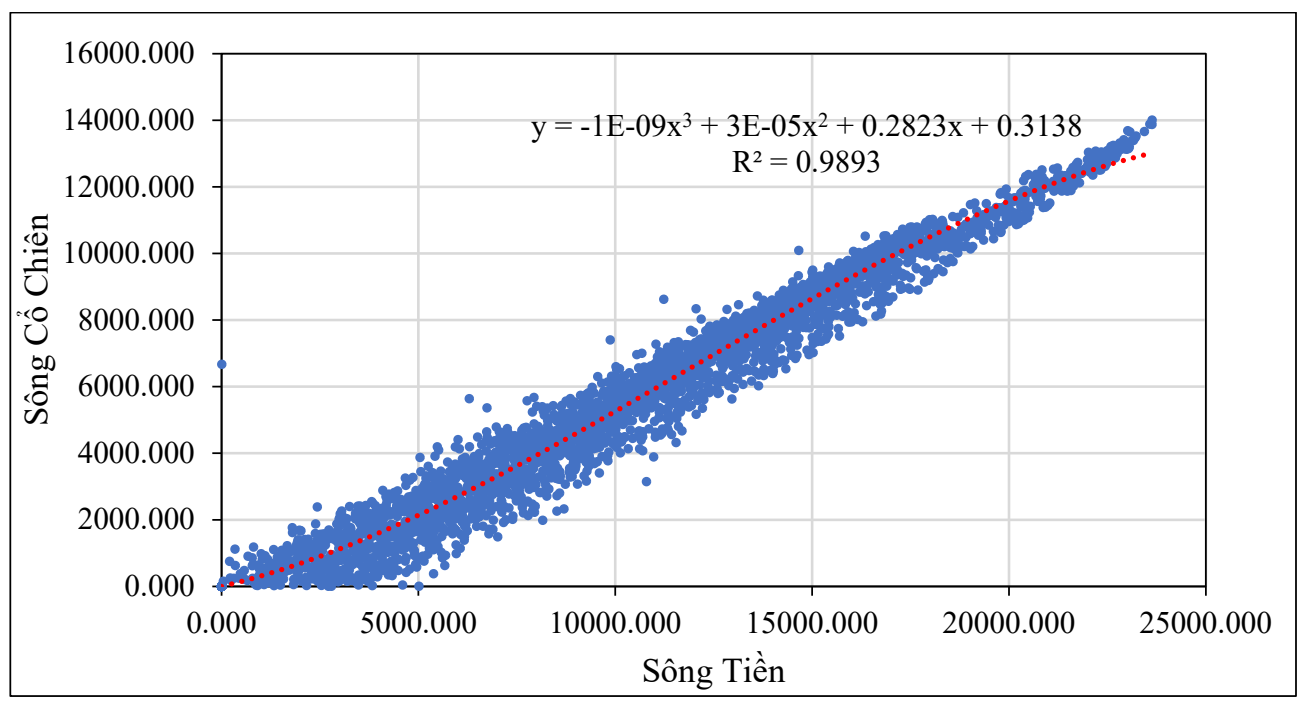

Hình 6. Đường quan hệ lưu lượng giờ tại nút phân lưu giữa sông Tiền và sông Cổ Chiên.

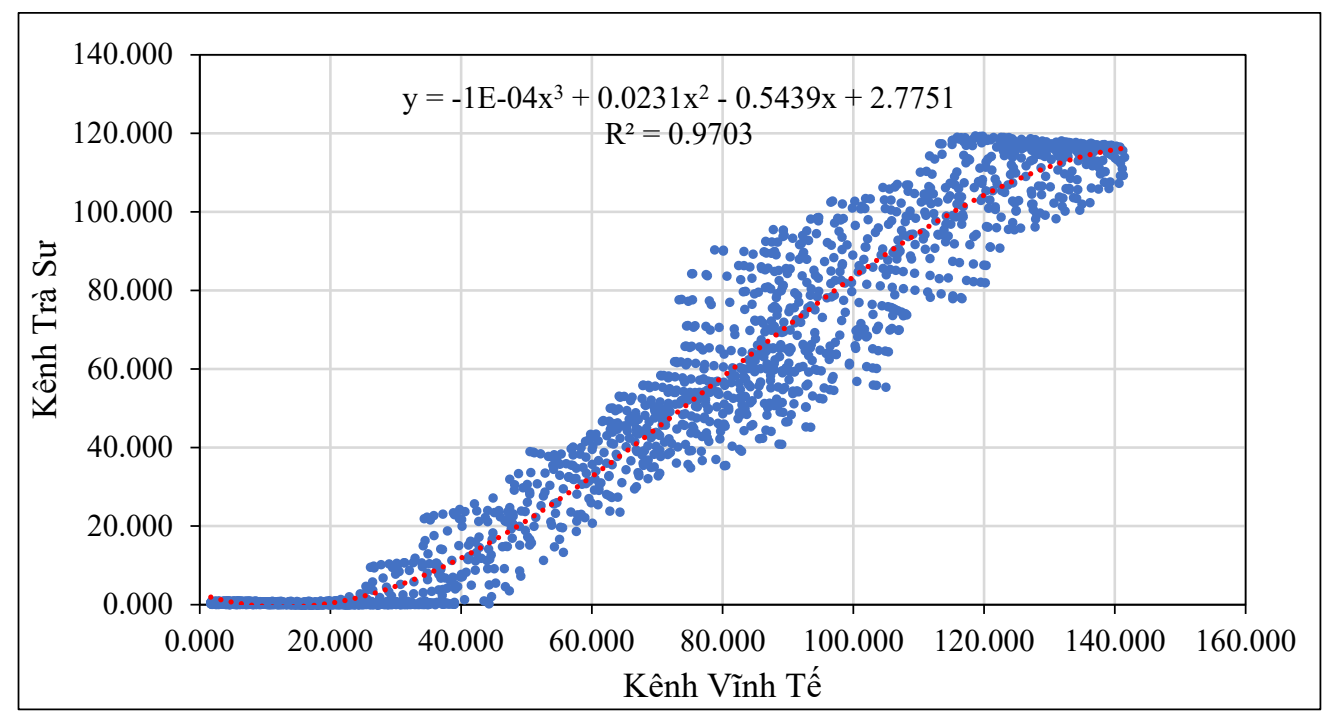

Hình 7. Đường quan hệ lưu lượng giờ tại nút phân lưu giữa kênh Vĩnh Tế và kênh Trà Sư. 
Quy tắc lấy nước tì̀ nhiều nút cấp (supply connections): một đối tượng sử dụng nước có thể lây nước từ nhiều nguồn/nút cấp. Để mô phỏng điều kiện thực tế, tỉ lệ nhu cầu nước được lấy từ các nút khác nhau được xác định bằng khả năng cấp nước của từng nút (với nguồn sông, kênh là khả năng tải và mật độ sông, kênh kết nối với sông, kênh biên; với nguồn nước dưới đất là trữ lượng có thể khai thác hoặc lấy theo hiện trạng, tiêu chuẩn, quy định thực tế). Trong nghiên cứu này, tỉ lệ nhu cầu nước của 1 đối tượng lấy từ 1 nút cụ thể được xác định bằng tỉ lệ lượng nước đến tại nút đó với tổng lượng nước đến tại tất cả các nút cấp cho đối tượng đang xét. Tỉ lệ này không cố định mà thay đổi theo ngày tương ứng với sự thay đổi của lượng nước đến từng nút:

$$
\text { Fraction }(\mathrm{ji})=\mathrm{Q}_{\mathrm{i}} / \Sigma \mathrm{Q}_{\mathrm{i}}
$$

Trong đó Fraction (ji) là tỉ lệ nhu cầu nước của đối tượng $\mathrm{j}$ lấy từ nút $\mathrm{i} ; \mathrm{n}$ là số nút cấp; $\mathrm{Q}_{\mathrm{i}}$ là lưu lượng nước đến nút $\mathrm{i} ; \Sigma \mathrm{Q}_{\mathrm{i}}$ là tổng lưu lượng nước đến tại tất cả các nút cấp cho đối tượng $\mathrm{j}$.

Khi đó nhu cầu nước của đối tượng $\mathrm{j}$ lấy từ nút $\mathrm{i}$ là:

$$
\mathrm{D}_{\mathrm{ji}}=\text { Fraction (ji) } \times \mathrm{D}_{\mathrm{j}}
$$

Trong đó $\mathrm{D}_{\mathrm{ji}}$ là nhu cầu nước của đối tượng $\mathrm{j}$ lấy từ nút $\mathrm{i} ; \mathrm{D}_{\mathrm{j}}$ là tổng nhu cầu nước của đối tượng $\mathrm{j}$ (từ tất cả các nút).

Quy tắc phân bổ nước tại nút ưu tiên (priority node): mô hình được thiết lập với 321 nút ưu tiên (hay nút cấp nước), là các nút tại đó nước được cấp cho nhiều đối tượng sử dụng. Các nút này mô phỏng các nguồn cấp là các sông, kênh biên của khu sử dụng nước và nguồn nước dưới đất. Để mô phỏng hiện trạng sử dụng nước thực tế, các đối tượng này đều được thiết lập mức ưu tiên như nhau (sử dụng nước đồng thời) nhưng với tỉ lệ phân bổ khác nhau. Trong nghiên cứu này, tỉ lệ phân bổ nước cho 1 đối tượng từ 1 nút được tính bằng tỉ lệ nhu cầu nước của đối tượng đó lấy từ nút đó (1 đối tượng có thể lấy nước từ nhiều nút) trên tổng nhu cầu nước của tất cả các đối tượng lấy nước từ nút đó:

$$
\text { Fraction }(\mathrm{ij})=\mathrm{D}_{\mathrm{ji}} / \Sigma \mathrm{D}_{\mathrm{i}}
$$

Trong đó Fraction (ij) là tỉ lệ cấp nước của nút $\mathrm{i}$ cho đối tượng $\mathrm{j} ; \mathrm{D}_{\mathrm{ji}}$ là nhu cầu nước của đối tượng $\mathrm{j}$ lấy từ nút $\mathrm{i} ; \Sigma \mathrm{D}_{\mathrm{i}}$ là tổng nhu cầu nước của tất cả các đối tượng lấy nước từ nút $\mathrm{i}$.

Khi đó lượng nước (tối đa) có thể cấp từ nút $\mathrm{i}$ cho đối tượng $\mathrm{j}$ là:

$$
\mathrm{Q}_{\mathrm{ij}}=\text { Fraction (ij) x } \mathrm{Q}_{\mathrm{i}}
$$

Trong đó $\mathrm{Q}_{\mathrm{ij}}$ là lưu lượng nước tối đa có thể cấp từ nút $\mathrm{i}$ cho đối tượng $\mathrm{j}$; $\mathrm{Q}_{\mathrm{i}}$ là tổng lưu lượng nước đến tới nút $\mathrm{i}$.

Quy tắc cho dòng chảy hồi quy (return flow connections): dòng chảy hồi quy từ một đối tượng sử dụng nước cũng có thể chảy vào nhiều nguồn sông, kênh khác nhau. Tỉ lệ hồi quy của một đối tượng tới một sông, kênh biên của khu sử dụng nước phụ thuộc vào mật độ sông, kênh kết nối tới sông, kênh biên đó, và phụ thuộc vào loại hình sử dụng nước của đối tượng đó (sinh hoạt, công nghiệp, trồng trọt, chăn nuôi, thủy sản, khác). Để đơn giản hóa, có thể lấy tỉ lệ hồi quy đều:

$$
\text { Fraction }\left(\mathrm{R}_{\mathrm{ji}}\right)=\text { Fraction }\left(\mathrm{R}_{\mathrm{j}}\right) \times\left(1 / \mathrm{n}_{\mathrm{k}}\right)
$$

Trong đó Fraction $\left(\mathrm{R}_{\mathrm{ji}}\right)$ là tỉ lệ hồi quy của đối tượng $\mathrm{j}$ tới kênh biên $\mathrm{i}$; Fraction $\left(\mathrm{R}_{\mathrm{j}}\right)$ là tỉ lệ hồi quy của loại hình sử dụng nước của đối tượng $\mathrm{j} ; \mathrm{n}_{\mathrm{k}}$ là số kênh biên.

Khi đó, lượng nước hồi quy từ đối tượng $\mathrm{j}$ tới kênh biên i là:

$$
\mathrm{R}_{\mathrm{ji}}=\operatorname{Fraction}\left(\mathrm{R}_{\mathrm{ji}}\right) \times \mathrm{U}_{\mathrm{j}}
$$

Trong đó $\mathrm{R}_{\mathrm{ji}}$ là lưu lượng nước hồi quy từ đối tượng $\mathrm{j}$ tới kênh biên $\mathrm{i} ; \mathrm{U}_{\mathrm{j}}$ là lưu lượng nước đã sử dụng bởi đối tượng $\mathrm{j}$. 


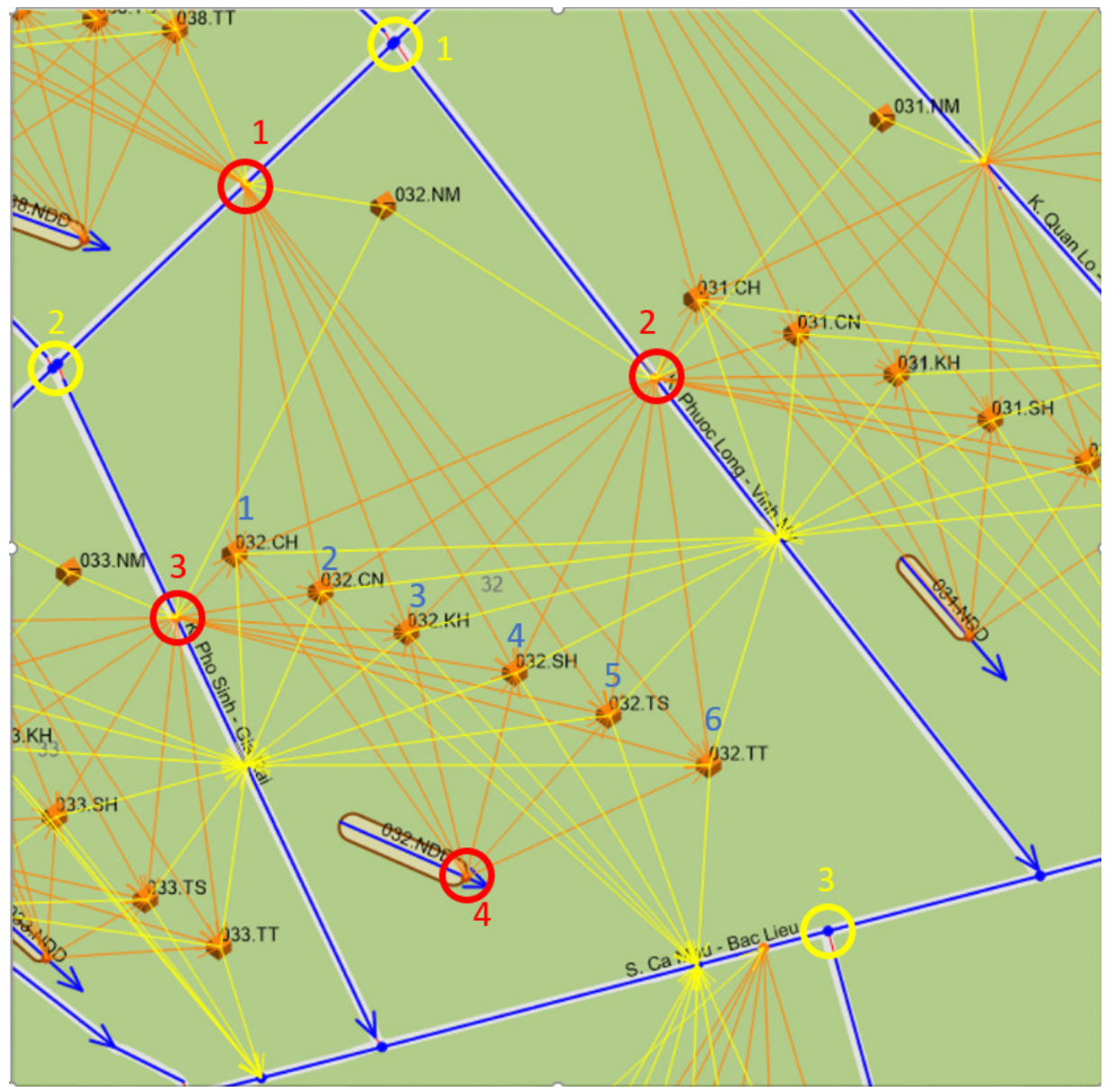

Hình 8. Các thành phần mô hình trong một khu sử dụng nước điển hình gồm 3 nút phân lưu, 4 nút cấp nước (3 nút từ kênh, 1 nút từ nguồn nước dưới đất), 6 đối tượng sử dụng nước, 1 nút nước mặt nội sinh từ mưa (032.NM) phân bổ vào các kênh, 3 nút nhận dòng chảy hồi quy.

\section{Kết quả và thảo luận}

\subsection{Kết quả tính toán cân bằng nước bằng mô hình $M H B$}

Mô hình MHB được thiết lập cho toàn vùng LVSCL và chạy với thời đoạn ngày cho năm 2020 để đánh giá hiện trạng mức độ đáp ứng của nguồn nước đối với các nhu cầu sử dụng nước ngọt khác nhau. Sử dụng phương pháp thiết lập các quy tắc phân bổ được trình bày ở mục 2 , quá trình phân bổ lượng nước ngọt từ các nguồn khác nhau (gồm nước mặt nội sinh từ mưa, nước mặt ngoại sinh chảy vào vùng qua sông Tiền, sông Hậu, sông Vàm Cỏ, và nhánh sông dọc theo biên giới Việt Nam-Campuchia, và nước dưới đất) cho các đối tượng sử dụng khác nhau được thực hiện đồng thời, tỉ lệ với nhu cầu của đối tượng và khả năng của nguồn nước, và không phân theo mức độ ưu tiên để phản ánh đúng với thực tế khai thác sử dụng.

Kết quả tính toán từ mô hình cho thấy, tổng lượng nước thiếu cả năm trên toàn vùng chiếm khoảng $11,4 \%\left(6,52\right.$ tỷ $\left.\mathrm{m}^{3}\right)$ so với tổng nhu cầu sử dụng nước $\left(57,42\right.$ tỷ $\left.\mathrm{m}^{3}\right)$, thời gian thiếu nhiều nhất vào tháng 2-4 (19,1-19,6\%), khu vực thiếu nhiều nhất là vùng bán đảo Cà Mau, đặc biệt là vùng Nam bán đảo Cà Mau, với tỉ lệ thiếu trung bình $25,5 \%$, các vùng còn lại gồm Tứ giác Long Xuyên, giữa sông Tiền-sông Hậu, và tả sông Tiền lượng thiếu không lớn kể cả vào mùa khô ngoại trừ một số khu vực giáp biển Đông và biển Tây thuộc vùng mặn (Hình 9-12). 


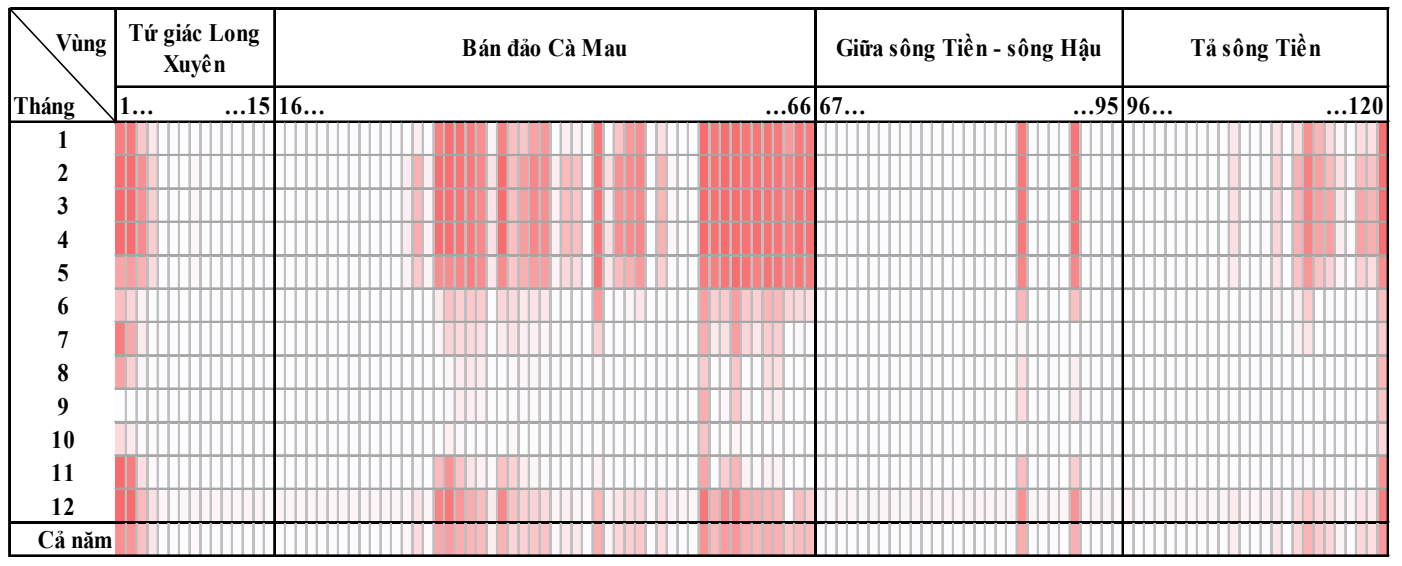

Hình 9. Tỉ lệ lượng nước thiếu (\%) trong các tháng và cả năm so với nhu cầu tại 120 vùng quản lý tổng hợp nguồn nước.

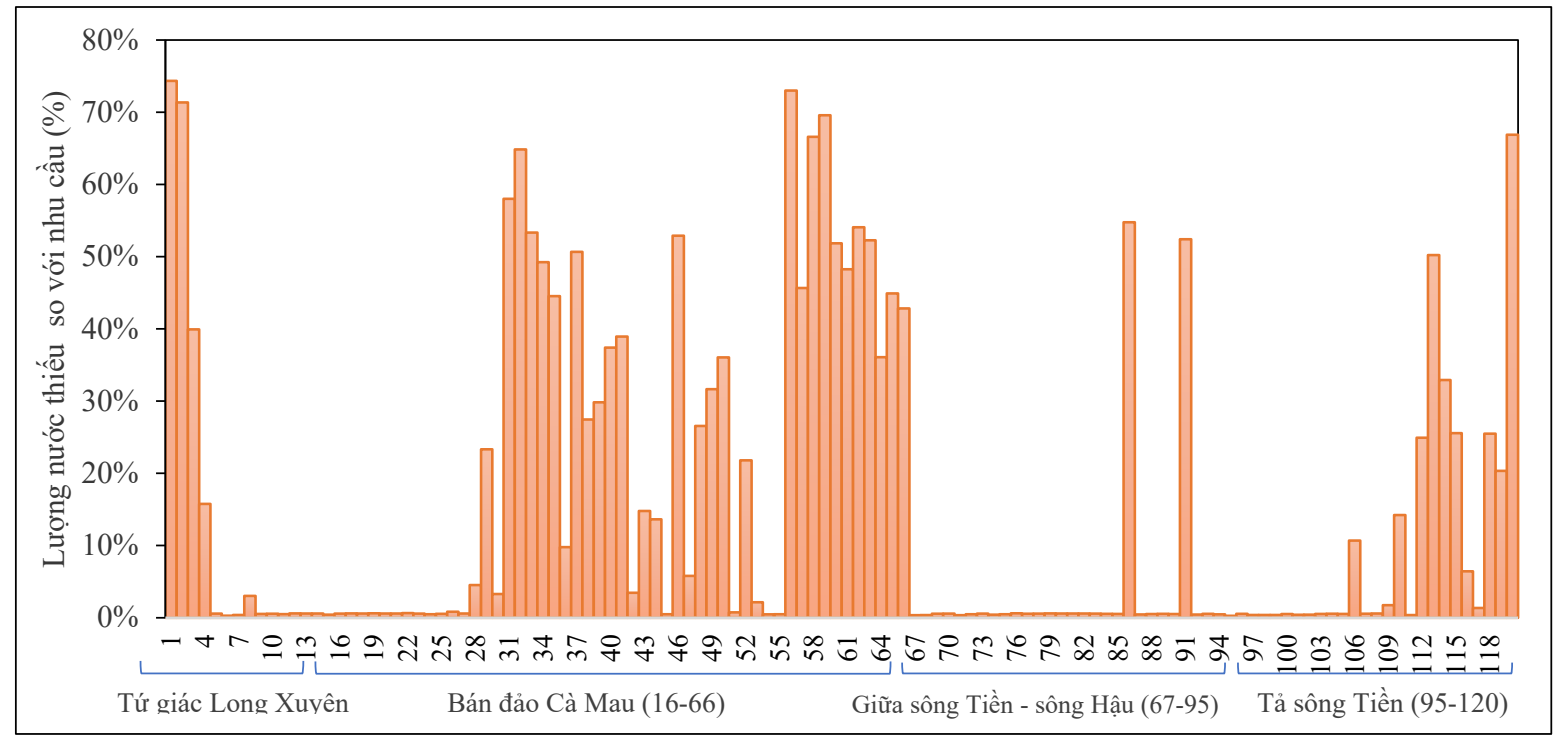

Hình 10. Tỉ lệ lượng nước thiếu (\%) so với nhu cầu cả năm trên 120 vùng quản lý tổng hợp nguồn nước.

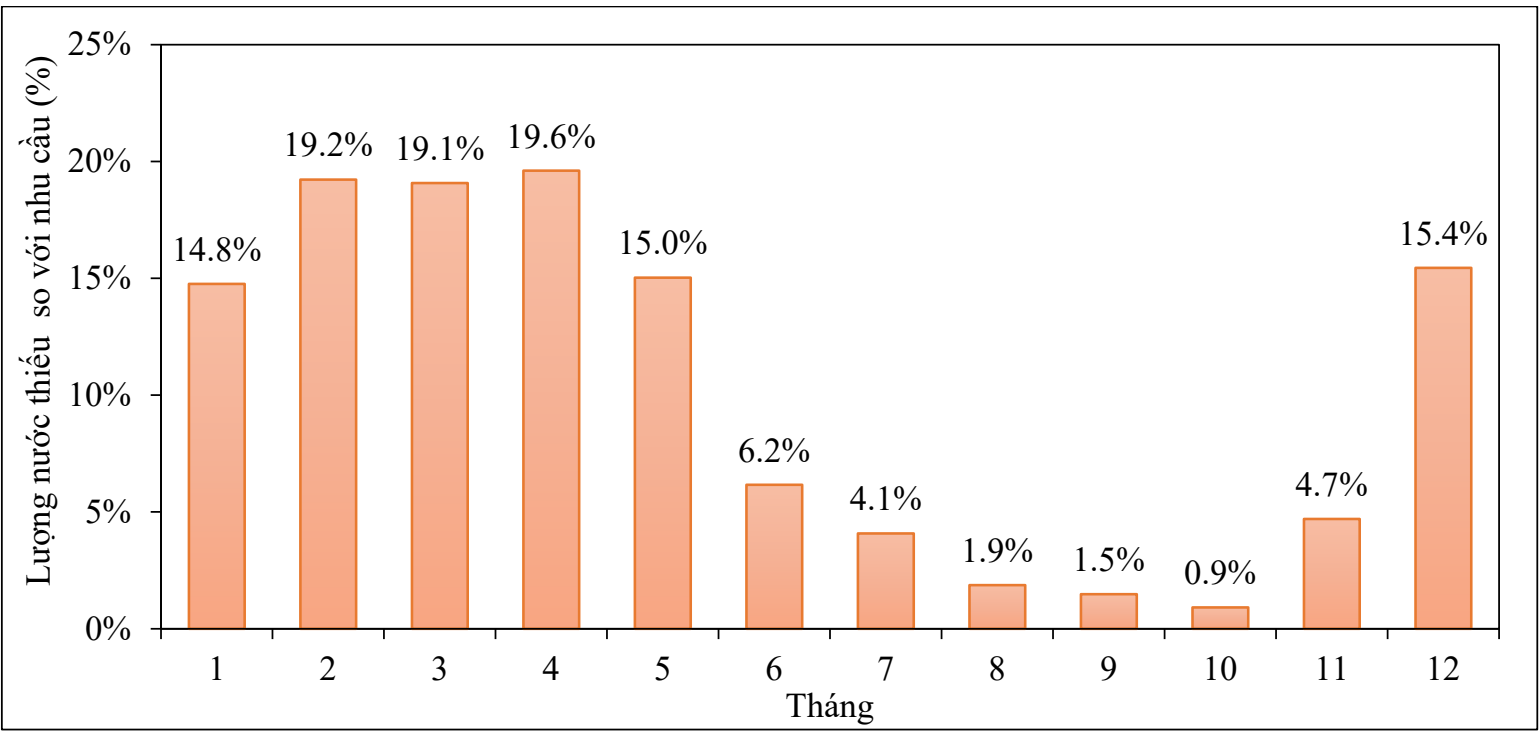

Hình 11. Tỉ lệ lượng nước thiếu (\%) so với nhu cầu trên toàn vùng trong từng tháng. 


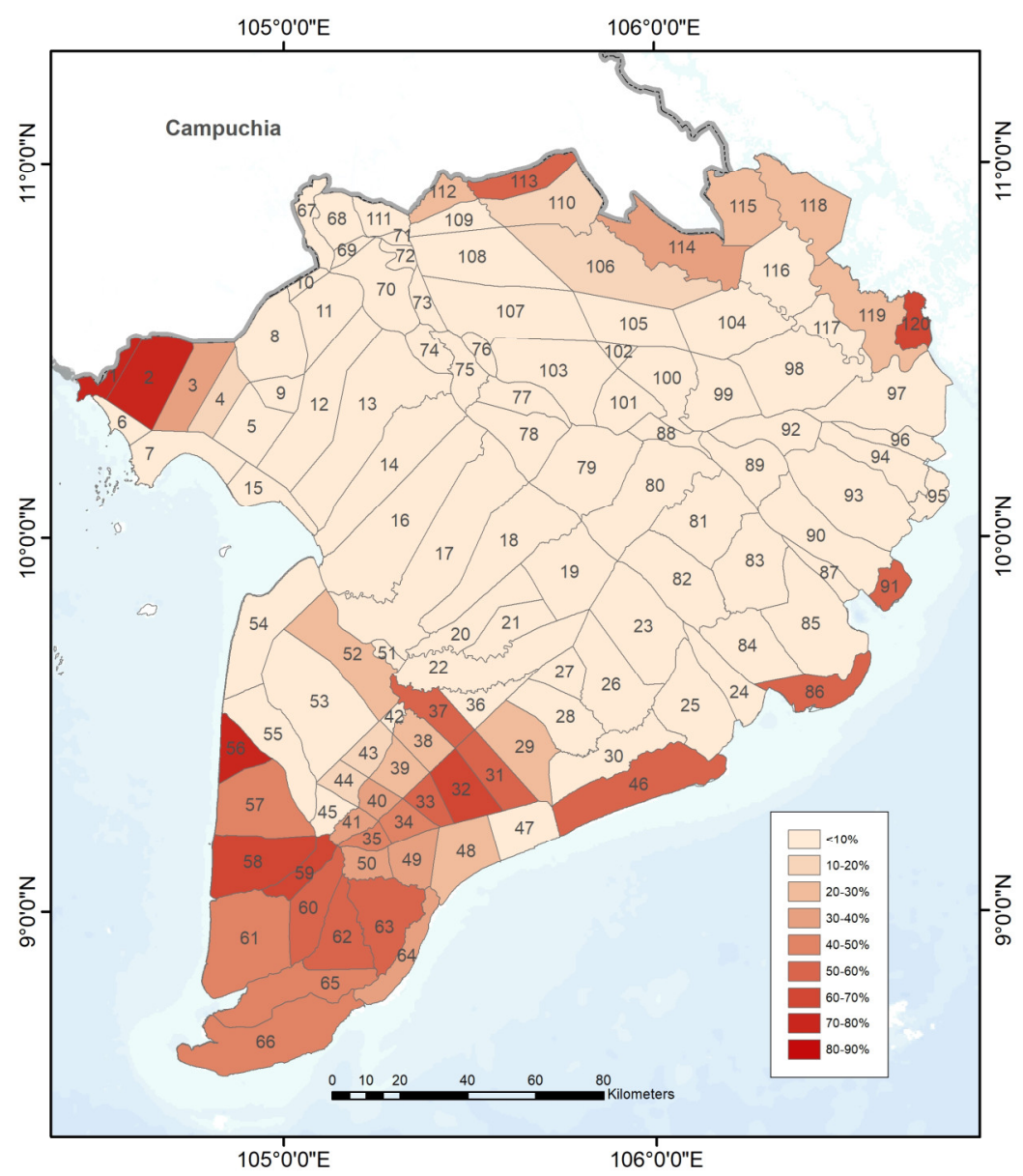

Hình 12. Bản đồ tỉ lệ lượng nước thiếu (\%) cả năm so với nhu cầu trên 120 vùng quản lý tổng hợp nguồn nước.

\subsection{Thảo luận}

Kết quả tính toán cân bằng nước bằng mô hình $\mathrm{MHB}$ cho năm hiện trạng về mặt tổng thể đã phản ánh tương đối chính xác thực tế khả năng đáp ứng của nguồn nước đối với các nhu cầu sử dụng nước ngọt khác nhau trên LVSCL. Tuy nhiên cần lưu ý rằng quá trình phân bổ nguồn nước trong nghiên cứu này hoàn toàn dựa trên số lượng, chưa đề cập tới chất lượng nước, đặc biệt là độ mặn do mô hình $\mathrm{MHB}$ chưa xem xét được yếu tố mặn và vận hành của các cống ngăn mặn. Việc này đặc biệt cần thiết trong bối cảnh mặn được dự báo sẽ thay đổi bất thường theo chế độ vận hành của các thủy điện ở thượng lưu [19]. Tại các khu sử dụng nước thuộc vùng mặn và lợ thuộc vùng bán đảo Cà Mau, đặc biệt là vùng Nam bán đảo Cà Mau và dọc theo kênh Quản Lộ - Phụng Hiệp, kết quả tính toán cũng cần được xem xét cẩn trọng hơn và kết hợp với đánh giá mặn từ mô hình thủy lực. Kết quả cân bằng số lượng nước tại các vùng này đã cho thấy sự thiết hụt, thực tế xâm nhập mặn sẽ gây ra sự thiết hụt nghiêm trọng hơn, điển hình là trong đợt hạn-mặn năm 2015-2016 với các tỉnh Kiên Giang, Cà Mau và Bạc Liêu là các địa phương bị thiệt hại lớn nhất [20]. Khu vực huyện Ngã Năm đầu kênh Phụng Hiệp (khu 27, 28, 29, 36) mặc dù từ kết quả tính toán cân bằng nước cho thấy không có thiếu hụt đáng kể xét trên lượng nước ngọt chuyển về, nhưng thực tế tại khu vực này nhiều thời điểm nước mặn đã thâm nhập sâu vào nội đồng cản trở việc lấy nước vào ruộng [21]. Vấn đề chất lượng nước cũng cần được kết hợp nghiên cứu đánh giá do trên thực tế có sự mâu thuẫn trong khai thác sử dụng tài nguyên nước mặt cho các hình thức sản xuất nông nghiệp khác nhau như canh tác lúa, hoa màu và nuôi trồng thủy sản bắt nguồn từ ô nhiễm do nước thải [22]. 
Trong phạm vi xem xét về số lượng nước, kết quả tính toán của mô hình MHB cho LVSCL trong nghiên cứu này phụ thuộc rất lớn vào các quy tắc được thiết lập để phân bổ dòng chảy, bao gồm các quy tắc về phân bổ lượng nước nội sinh từ mưa vào các sông/kênh, tỉ lệ phân lưu giữa các nhánh sông/kênh, phân bổ nhu cầu nước đối với từng nguồn cấp, phân bổ nguồn cấp cho từng đối tượng sử dụng nước, phân bổ dòng chảy hồi quy trở lại từng nguồn cấp. Tất cả các quy tắc này đều cần được tinh chỉnh để phản ánh sát nhất với điều kiện khai thác thực tế. Điều này có thể được thực hiện thông qua phân tích hiện trạng hệ thống sông, kênh và kết quả từ mô hình thủy lực. Hai trở ngại chính ảnh hưởng đến tính hợp lý của kêt quả cân bằng nước bằng mô hình $\mathrm{MHB}$ trên LVSCL (và các vùng tương tự với mạng sông/kênh phức tạp) gồm: xác định tỷ lệ phân lưu giữa các nhánh sông/kênh, và tỉ lệ phân bổ giữa nhiều nguồn nước cho nhiều đối tượng khác nhau.

Tỷ lệ phân lưu được nhập vào mô hình dưới dạng đường quan hệ lưu lượng giữa dòng chính và dòng nhánh, được xác định từ kết quả tính toán của mô hình thủy lực, do đó đã bao gồm ảnh hưởng của triều. Tuy nhiên tại các vị trí chịu ảnh hưởng triều lớn, quan hệ giữa lưu lượng giờ hoặc lưu lượng trung bình ngày giữa dòng chính và dòng nhánh thường không chặt, đặc biệt khi sông chính và sông nhánh chịu ảnh hưởng triều từ hai hướng khác nhau (biển Đông và biển Tây). Ngoài ra, ảnh hưởng của lũ tràn biên giới cũng làm cho quan hệ lưu lượng giữa dòng chính và dòng nhánh trở nên rất phức tạp, khó chặt chẽ, có những thời điểm trong ngày từ vị trí là điểm phân lưu biến thành nhập lưu hoặc ngược lại do dòng chảy trung bình đổi chiều. Do đó, việc chia mô hình chạy riêng rẽ cho mùa lũ và mùa kiệt sẽ đảm bảo mô phỏng tốt, độ tin cậy cao hơn do chiều dòng chảy trung bình ngày hoặc thời đoạn lớn hơn là khá ổn định theo từng mùa.

Đối với việc xác định tỷ lệ phân bổ nguồn nước, do các sông/ kênh nối với nhau theo mạng lưới rất phức tạp, một đối tượng có thể sử dụng từ nhiều nguồn cấp (các nhánh sông/kênh khác nhau) và một nguồn cấp có thể phân phối cho nhiều đối tượng, nên việc xác định các tỷ lệ phân phối giữa nguồn cấp và đối tượng sử dụng sát với thực tế là bài toán thử dần và tuân theo nguyên tắc nguồn lớn sẽ cấp được nhiều và đối tượng sử dụng nhiều sẽ được cấp nhiều, nhằm mục đích cuối cùng là xác định được khả năng đáp ứng tối đa của nguồn nước cho các mục đích sử dụng. Ngoài ra, trên các khu vực có các cống điều tiết, bài toán sẽ trở nên phức tạp hơn khi phải mô phỏng và tối ưu hóa vận hành của cống để đảm bảo đủ nước, như trong các nghiên cứu [23-24]. Trong nghiên cứu này, các tỷ lệ phân phối là không cố định và được tính toán thay đổi theo từng ngày, tương ứng với sự thay đổi của lượng nước đến tại từng nguồn cấp và nhu cầu của đối tượng. Tuy nhiên có thể đơn giản hóa để giảm khối lượng tính toán bằng cách sử dụng các tỷ lệ trung bình hợp lý, cố định tùy thuộc vào yêu cầu về độ chính xác của bài toán.

\section{Kết luận}

Nghiên cứu này đã áp dụng mô hình cân bằng nước MIKE HYDRO BASIN để tính toán khả năng đáp ứng của nguồn nước với các nhu cầu sử dụng nước khác nhau trên lưu vực sông Cửu Long. Mô hình được thiết lập với các dữ liệu đầu vào là lượng nước mặt nội sinh từ mưa, lượng nước mặt ngoại sinh chảy vào vùng từ sông Mê Kông, sông Vàm Cỏ, và các sông nhánh tại biên giới Việt Nam-Campuchia, lượng nước dưới đất có thể khai thác, và nhu cầu sử dụng nước của 06 đối tượng gồm sinh hoạt, công nghiệp, trồng trọt, chăn nuôi, thủy sản, và các ngành khác. Kết quả tính toán cân bằng nước tại 120 vùng quản lý tổng hợp nguồn nước trên lưu vực phản ánh tương đối sát với hiện trạng khả năng đáp ứng nguồn nước trên thực tế. Tổng lượng nước thiếu cả năm trên toàn vùng chiếm khoảng $11,4 \%$ so với tổng nhu cầu sử dụng nước, thời gian thiếu nhiều nhất vào tháng $2-4$, khu vực thiếu nhiều nhất là vùng bán đảo Cà Mau, đặc biệt là vùng Nam bán đảo Cà Mau, với tỉ lệ thiếu trung bình $25,5 \%$, các vùng còn lại gồm Tứ giác Long Xuyên, giữa sông Tiền-sông Hậu, và tả sông Tiền lượng 
thiếu không lớn kể cả vào mùa khô ngoại trừ một số khu vực giáp biển Đông và biển Tây thuộc vùng mặn.

Bằng cách sử dụng một số giả định về chiều dòng chảy theo lưu lượng trung bình và các kết quả tính toán từ mô hình thủy lực MIKE 11HD, mô hình MIKE HYDRO BASIN hoàn toàn có thể được sử dụng để tính toán cân bằng nước và lựa chọn phương án phân bổ nguồn nước trên lưu vực sông Cửu Long phục vụ mục đích quy hoạch. Với đặc thù mạng lưới sông kênh phức tạp, không có lưu vực rõ ràng, để đảm bảo tính hợp lý của kết quả tính toán, việc xác định các quy tắc phân bổ trong mô hình theo khả năng của nguồn nước và nhu cầu sử dụng nước là hết sức quan trọng. Ngoài ra, do phạm vi ứng dụng của mô hình chỉ xem xét đển số lượng nước, kết quả tính toán từ mô hình MIKE HYDRO BASIN nên được kết hợp với các đánh giá về độ mặn và chất lượng nước từ các mô hình khác để có thể đưa ra được kết luận đầy đủ hơn về khả năng đáp ứng của nguồn nước đối với các mục đích sử dụng khác nhau.

Đóng góp của tác giả: Xây dựng ý tưởng nghiên cứu: N.N.H., Đ.T.D.; Lựa chọn phương pháp nghiên cứu: Đ.T.D., N.N.H., H.T.N.M.; Xử lý số liệu: Đ.T.D.; H.T.N.M.; Chạy mô hình: Đ.T.D.; N.N.H.; Xử lý GIS và bản đồ: Đ.T.D.; Phân tích kết quả N.N.H.; H.T.N.M.; Đ.T.D.; Viết bản thảo bài báo: N.N.H.; Đ.T.D., H.T.N.M.; Chỉnh sửa bài báo: N.N.H., H.T.N.M; Đ.T.D.

Lời cảm ơn: Nghiên cứu này được thực hiện trong khuôn khổ Đề tài "Nghiên cứu xây dựng bộ công cụ tích hợp đánh giá tài nguyên nước và đất phục vụ quy hoạch tổng thể đồng bằng sông Cửu Long" mã số ĐTĐL.CN-44/18. Nhóm tác giả xin trân trọng cám ơn sự hỗ trợ quý báu này.

Lời cam đoan: Tập thể tác giả cam đoan bài báo này là công trình nghiên cứu của tập thể tác giả, chưa được công bố ở đâu, không được sao chép từ những nghiên cứu trước đây; không có sự tranh chấp lợi ích trong nhóm tác giả.

\section{Tài liệu tham khảo}

1. Thái, T.H.; Tuyển, H.M.; Dũng, L.H.; Tiến, N.X.; Anh, T.Đ. Diễn biến dòng chảy ở Đồng bằng sông Cửu Long. Tạp chi Khí tương thủy văn, 2014, 643, 19-23.

2. DHI. Mike Hydro Basin User Guide, 2011.

3. Stockholm Environment Institute. WEAP User Guide, 2015.

4. Tổng cục Thống kê. Niên giám thống kê 13 tỉnh vùng Đồng bằng sông Cửu Long. NXB Thống kê, 2019.

5. Trung tâm Quy hoạch và Điều tra tài nguyên nước quốc gia. Lập nhiệm vụ Quy hoạch tài nguyên nước lưu vực sông Cửu Long. Báo cáo thuyết minh, Hà Nội, 2020, tr. 119.

6. Viện Quy hoạch thủy lợi miền nam. Quy hoạch tổng thể thuỷ lợi đồng bằng sông Cửu Long trong điều kiện biến đổi khí hậu-nước biển dâng. Báo cáo thuyết minh, TPHCM, 2009, tr. 411.

7. Văn, C.T.; Sơn, N.T. Nghiên cứu mô phỏng thủy văn, thủy lực vùng đồng bằng sông Cửu Long để đánh giá ảnh hưởng của hệ thống đê bao đến sự thay đổi dòng chảy mặt vùng Đồng Tháp Mười. VNU J. Sci.: Earth Environ. Sci. 2016, 32 (3S), 256-263.

8. Trung tâm Quy hoạch và điều tra tài nguyên nước quốc gia. Bảo vệ nước dưới đất ở các đô thị lớn. Đề cương nhiệm vụ, 2015, tr. 205.

9. Xuân, T.T.; Tuyển, H.M.; Thục, T.; Thái, T.H.; Dũng, N.K. Tài nguyên nước hệ thống sông chính Việt Nam. Sách chuyên khảo NXB KH\&KT, Hà Nội, 2012, tr. 268.

10. Tổng cục Khí tượng Thủy văn (VNMHA). http://kttvqg.gov.vn/

11. https://portal.mrcmekong.org/

12. Hà, N.N.; Giang, N.T. Tài nguyên nước mặt lưu vực sông Vệ. Tạp chí Khoa học ĐHQGHN: Khoa học Tụ nhiên và Công nghệ. 2015, 31(3S), 104-115. 
13. WUP-JICA. Part III: Hydro-Hydraulic modelling. Vol. I: Main report, Mekong delta flood warning and monitoring system project. 2004, p 125.

14. Viện Khoa học thủy lợi miền Nam. Quy hoạch thuỷ lợi vùng nam bán đảo Cà Mau. Báo cáo thuyết minh, 2009.

15. Bộ Xây Dựng. Quy hoạch cấp nước vùng Đồng bằng sông Cửu long đến năm 2030 tầm nhìn đến năm 2050. Báo cáo chính, Hà Nội, 2016, tr. 205

16. Bộ Kế hoạch và Đầu tư. Quy hoạch vùng Đồng bằng sông Cửu Long thời kỳ 20212030, định hướng đến năm 2050. Báo cáo chính, Hà Nội, 2021, tr. 599.

17. Ủy Hội sông Mê Công (MRC). Nghiên cứu tác động của các công trình thủy điện trên dòng chính sông Mê Công, Tập 1-Mô hình-thiết kế mô hình và mô phỏng. Báo cáo chính, MRC-Viêng Chăn (Lao PDR), 2016, tr. 204.

18. Eslami, S.; Hoekstra, P.; Kernkamp, H.; Trung, N.N.; Duc, D.D.; Quang, T.T.; Februarianto, M.; Dam, A.V.; van der Vegt, M. Flow Division Dynamics in the Mekong Delta: Application of a 1D-2D Coupled Model. Water 2019, 11(4), 837.

19. Thắng, T.Đ.; Hoằng, T.B.; Vượng, N.Đ.; Toản, T.Q.; Tuấn, T.M.; Thịnh, L.V. Một số vấn đề về dòng chảy và xu thế mặn xâm nhập vùng đồng bằng sông Cửu Long. Tạp chi Khoa họ và công nghẹ thủy lợi 2020, 58, 1-9.

20. Thuấn, N.Q.; Ngọc, H.H.; An, P.S. Giải pháp thích ứng với biến đổi khí hậu ở đồng bằng sông Cửu Long trong bối cảnh mới. Tạp chí Khoa học xã hội Việt Nam 2019, 3. https://www.vass.gov.vn/tap-chi-vien-han-lam/giai-phap-thich-ung-voi-bien-doikhi-hau-o-dong-bang-song-cuu-long-trong-boi-canh-moi-16\#tab_01.

21. Hoàng, H.M.; Trí, P.V.Đ.; Trung, N.H. Quản lý nguồn nước mặt cho hệ thống canh tác lúa vùng ven biển đồng bằng sông cửu long. Tạp chí Khoa học Truờng Đại học Cần Tho 2014, 35, 90-103.

22. Khánh, N.T.; Trí, V.P.Đ.; Diễm, N.T.K.; Hằng, T.T.L. Công tác quản lý nguồn tài nguyên nước mặt trong sản xuất nông nghiệp vùng ven biển đồng bằng sông Cửu Long dưới tác động của biến đổi khí hậu. Tạp chí Khoa học Truờng Đại học Cần Tho 2015, 159-166.

23. Shyam, R.; Chauhan, H.S.; Sharma, J.S. Optimal operation scheduling model for a canal system. Agric. Water Manage. 1994, 26(3), 213-225.

24. Mathur, Y.P.; Sharma, G. Optimal Operation Scheduling of Irrigation Canals Using Genetic Algorithm. Int. J. Recent Trends Eng. 2009, 1(6), 11-15.

\title{
Water balance model development for integrated water resources planning on the Cuu Long River basin
}

\author{
Nguyen Ngoc $\mathrm{Ha}^{1 *}$, Hoang Thi Nguyet Minh², Dinh Tien Dung ${ }^{1}$ \\ ${ }^{1}$ National Center for Water Resource Planning and Investigation, Ministry of Natural \\ Resources and Environment, 93/95 Vu Xuan Thieu, Sai Dong, Long Bien, Ha Noi; \\ ha_tnn@yahoo.com; dungdt812@gmail.com \\ ${ }^{2}$ Hanoi University of Natural resources and Environment (HUNRE), 41 Phu Dien, Bac Tu \\ Liem, Ha Noi; htnminh.tnn@hunre.edu.vn
}

\begin{abstract}
This paper studies the application of the MIKE HYDRO BASIN (MHB) water balance model to assess the responsiveness of water sources for different water needs in the Cuu Long River basin. The entire river basin is divided into 120 integrated water resources management zones. Water demand is calculated for 6 uses including domestic, industrial, farming, livestock, aquaculture, other needs, and is limited to freshwater. The MHB model calculates the water balance on a daily basis for the current status year 2020, in order to determine in detail the total amount of water shortage for the whole year, the time of water shortage in the year, the months of water shortage in the whole river basin and over 120
\end{abstract}


management zones. Calculation results show that the total amount of water shortage for the whole year in the entire river basin accounts for about $11.4 \%$ of the total water demand, the most shortage time is in February-April (19.1-19.6\%). The area with the most water deficit is the Ca Mau Peninsula. The MHB model applied to the Cuu Long River basin can be used as a quick and convenient assessment tool to assess the responsiveness of water resources to different planning scenarios, thereby serving as a basis for the selection of appropriate water resource allocation options.

Keywords: Mekong; Cuu Long River; Water resources; Water balance; Mike Hydro Basin model. 